\title{
Variation in Yield, Starch, and Protein of Dry Pea Grown across Montana
}

\author{
Aifen Tao, Reza Keshavarz Afshar, Jinwen Huang, Yesuf Assen Mohammed, \\ Matthew Espe, and Chengci Chen*
}

\begin{abstract}
Pea (Pisum sativum L.) has long been an important component of the human diet, providing an excellent source of protein. In addition to its protein, pea starch, especially resistant starch (RS), has received an extensive attention in food industries in recent years. We evaluated nine pea cultivars varying in cotyledon color, grain weight, maturity group, and phenology planted at five locations with diverse climatic conditions across Montana in 2013 and 2014 to assess genetic and environmental factors affecting their yield, protein, RS, and total starch (TS). Grain yield varied from 982 to $5951 \mathrm{~kg} \mathrm{ha}^{-1}$, RS content ranged from 5 to $53 \mathrm{~g} \mathrm{~kg}^{-1}$, and protein from 159 to $251 \mathrm{~g} \mathrm{~kg}^{-1}$. Statistical analysis showed that environment was the most important driving factor in grain yield, protein, and TS determination whereas RS content was mainly determined by cultivar. Drought at all phenological stages reduced pea yield and different cultivars tended to respond differently. Yield was positively correlated with protein, implying a potential to select/breed a cultivar with higher yield and protein. Protein was negatively correlated with TS, thus protein- or starch-type cultivars may be bred for different end users. Compared to other cultivars tested, DS Admiral was the most promising one with above average yield, protein, and RS.
\end{abstract}

\section{Core Ideas}

- Dry pea yield, protein, and resistant starch varied greatly across Montana.

- Yield and protein were mainly determined by environments.

- Resistant starch is controlled by genetics to a great extent.

- Effects of drought index, growth period, seed size, and seed weight on yield, protein, and starch were analyzed.

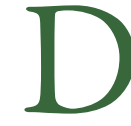
RY PEA has long been known as an excellent source of protein in human and livestock diet (Hood-Niefer et al., 2012), and plays an important role in sustainable cropping systems worldwide. In the U.S. northern Great Plains (NGP), a shift toward a cereal-dry pea cropping system has been a major trend of the agricultural industry (Long et al., 2014). Intensification and diversification of the cropping systems with pulse crops, mainly dry pea, in this region has brought benefits to growers by creating an immediate economic return, providing typical rotational benefit, and offering $\mathrm{N}$ credit for the subsequent crop yield and grain quality (Chen et al., 2012; Ito et al., 2016).

Some efforts have been made to quantify yield variation of dry pea across NGP. For example, Ito et al. (2016) evaluated adaptation and yield stability of dry pea cultivars across Montana from 2009 to 2011. They reported that a large portion of the total variation of yield was explained by the environment (E). In that study, Delta, Majoret, and Cruiser were found as suitable cultivars with general adaptation to Montana environment. However, quality characteristics, such as protein and starch, were not evaluated in that study.

Similar to other agricultural commodities, yield and nutritional characteristics of dry pea affect the benefits of both producers and end-users. For farmers, a high-yielding cultivar with desirable quality for buyers will maximize farm income, while for end-users various nutritional or chemical characteristics are required for different food and feed purposes. Traditionally, protein has been considered the most important component of pea grains governing end-use quality (Tzitzikas et al., 2006). In developing countries such as India, for example, dry pea is mainly split for dal as a protein source in the human diet, whereas in developed countries dry pea is primarily considered

\author{
Published in Agron. J. 109:1491-1501 (2017) \\ doi:10.2134/agronj2016.07.0401 \\ Available freely online through the author-supported open access option
}

Copyright ( 2017 American Society of Agronomy

5585 Guilford Road, Madison, WI 53711 USA

This is an open access article distributed under the CC BY-NC-ND

license (http://creativecommons.org/licenses/by-nc-nd/4.0/)
C. Chen, R.K. Afshar, and Y.A. Mohammed, Montana State Univ.-Eastern Agricultural Research Center, 1501 N. Central Ave. Sidney, MT 59270; A. Tao and J. Huang, Fujian Agriculture and Forestry Univ., -Key Laboratory of Ministry of Education for Genetics, Breeding and Multiple Utilization of Crops, Key Laboratory of Crops by Design, Fuzhou, Fujian 350002, China; M. Espe, Univ. of California Davis-Plant Sciences, One Shields Avenue, Davis, CA 95616. Received 12 July 2016. Accepted 10 Mar. 2017. *Corresponding author (cchen@montana.edu).

Abbreviations: AMMI, additive main effect and multiplicative interaction; E, environment; G, cultivar; GE, interaction of cultivar $\times$ environment; GEN, interaction of cultivar $\times$ environment noise; GES, interaction of cultivar $\times$ environment signal; NGP, northern Great Plains; NRS, non-resistant starch; PC, principal component; PDI, modified palmer drought index; RS, resistant starch; SS, sum of square; TS, total starch. 
an excellent high-protein feedstuff (Annicchiarico and Iannucci, 2008). In addition to $20 \%$ (w/w) protein (on average), dry pea contains $46 \%$ starch and $20 \%$ fiber (Tzitzikas et al., 2006). Although pea is not considered a major source of edible starch (compared to rice [Oryza sativa L.], wheat [Triticum aestivum L.], corn [Zea mays L.], and potato [Solanum tuberosum L.]), pea starch is now widely processed to noodles in food industries (Ratnayake et al., 2002). In fact, pea starch is considered the second best material \{after mung bean [Vigna radiata (L.) Wilczek] among all grain legumes for processing starch noodles (Tan et al., 2009).

In the process of digestion, a proportion of starch, which is called RS, escapes from digestion in the small intestine of healthy individuals within $120 \mathrm{~min}$ but fermented in the colon (Sun et al., 2015). A literature review conducted by Sajilata et al. (2006) described that RS has physiological functions similar to those of dietary fibers. Resistant starch can potentially help individuals control diabetes and energy balance, and the short-chain fatty acids produced by fermenting colonic bacteria provide direct health benefits to the colon (Birt et al., 2013). Due to the considerable health benefits, RS has attracted substantial attention in recent years (Haenen et al., 2013; Sun et al., 2015). Variable contents of RS among different genotypes of rice (Chiu and Stewart, 2012) and wheat (Hazard et al., 2012) have been reported. Strydhorst et al. (2015) found winter pea (cultivar Windham) had lower starch but higher resistant starch and protein than spring pea cultivars. However, research is needed regarding the variation of RS and protein among dry pea cultivars growing in different environments. Very little knowledge exists regarding the influence of environmental factors and agronomic management on the composition of dry pea, especially RS and protein contents.

The objective of this study was to investigate the variation of yield, protein, TS, and RS in dry pea grown in different environments across Montana.

\section{MATERIALS AND METHODS}

\section{Site Description}

Field trials were conducted at five experimental locations (Central Agricultural Research Center near Moccasin, Northern Agricultural Research Center near Havre, Northwestern Agricultural Research Center near Creston, Southern Agricultural Research Center near Huntley, and Western Triangle Research Center near Conrad) across the state of Montana during 2013 and 2014. Montana is the fourth largest state and the largest dry pea producer in the United States (USDA-NASS, 2014) with diverse climate and soil conditions. Geographic coordinates and soil types of the experimental sites are provided in Table 1 .

Weather parameters, including monthly cumulative precipitation and average temperature during the growing season at each site, are given in Table 2.

\section{Experimental Design}

General agronomic practices at the experimental sites are summarized in Table 3. Starter fertilizer, mainly P, was applied at Conrad and Creston in 2013 and 2014 based on pre-plant soil test. According to previous studies by Chen et al. (2006)

Table I. Geographic coordinate, altitude and soil type at the experimental locations.

\begin{tabular}{lccl}
\hline Location & Geographic coordinate & Altitude & Soil type \\
\hline & & $\mathrm{m}$ & \\
Conrad & $48^{\circ} 14^{\prime} \mathrm{N}, 111^{\circ} 55^{\prime} \mathrm{W}$ & 1117 & fine, smectitic, frigid Aridic Argiustoll (Scobey clay loam series) \\
Creston & $48^{\circ} \mathrm{II} \mathrm{I}^{\prime} \mathrm{N}, 114^{\circ} 08^{\prime} \mathrm{W}$ & 905 & coarse-silty, mixed, Udic Haploboroll (Creston silt loam series) \\
Havre & $48^{\circ} 30^{\prime} \mathrm{N}, 109^{\circ} 47^{\prime} \mathrm{W}$ & 823 & fine-loamy, mixed, superactive, frigid Aridic Argiustoll (Joplin clay loam series) \\
Huntley & $45^{\circ} 55^{\prime} \mathrm{N}, 108^{\circ} \mathrm{I} 4^{\prime} \mathrm{W}$ & 920 & fine-loamy, mixed, superactive, mesic Aridic Haplustalf (Fort Collins clay loam series) \\
Moccasin & $47^{\circ} 03^{\prime} \mathrm{N}, 109^{\circ} 57^{\prime} \mathrm{W}$ & 1295 & fine-loamy, carbonatic Typic Calciboroll (Judith clay loam series) \\
\hline
\end{tabular}

Table 2. Monthly precipitation and average temperature at each location in 2013 and 2014 growing season.

\begin{tabular}{|c|c|c|c|c|c|c|c|c|c|c|}
\hline \multirow[b]{2}{*}{ Month } & Conrad & Creston & Havre & Huntley & Moccasin & Conrad & Creston & Havre & Huntley & Moccasin \\
\hline & \multicolumn{5}{|c|}{2013} & \multicolumn{5}{|c|}{2014} \\
\hline & \multicolumn{10}{|c|}{ Precipitation, $\mathrm{mm}$} \\
\hline Mar. & 5 & 16 & 0 & 6 & 2 & 20 & 59 & 13 & 55 & 28 \\
\hline Apr. & 9 & 54 & II & 30 & 17 & 22 & 19 & 18 & 30 & 16 \\
\hline May & 31 & 84 & 89 & 154 & 80 & 40 & 29 & 12 & 58 & 41 \\
\hline June & 106 & 70 & 142 & 36 & 96 & 63 & 162 & 49 & 7I & 62 \\
\hline July & 28 & I & 55 & 16 & 43 & 48 & 12 & II & II & 34 \\
\hline Aug. & 30 & 23 & 27 & 37 & 24 & 31 & 43 & 96 & 93 & 170 \\
\hline \multirow[t]{2}{*}{ Sept. } & 23 & 67 & 38 & 104 & 96 & 50 & 19 & 18 & 19 & 59 \\
\hline & \multicolumn{10}{|c|}{ Temperature, ${ }^{\circ} \mathrm{C}$} \\
\hline Mar. & 0 & I & -1 & 2 & 0 & -5 & 0 & -3 & 0 & -2 \\
\hline Apr. & 3 & 4 & 4 & 5 & 2 & 4 & 5 & 6 & 8 & 3 \\
\hline May & 10 & II & 12 & 14 & 10 & 10 & II & II & 13 & 9 \\
\hline June & II & 14 & 16 & 18 & 14 & 12 & 13 & 14 & 16 & 12 \\
\hline July & 18 & 19 & 20 & 22 & 20 & 19 & 19 & 20 & 22 & 20 \\
\hline Aug. & 19 & 18 & 21 & 23 & 20 & 18 & 18 & 19 & 21 & 18 \\
\hline Sept. & 14 & 14 & 16 & 18 & 15 & 12 & 12 & 13 & 15 & 12 \\
\hline
\end{tabular}


and Wen et al. (2008) in Montana, 23 to $34 \mathrm{~kg} \mathrm{P}_{2} \mathrm{O}_{5} \mathrm{ha}^{-1}$ should be added when soil test showing an Olsen $\mathrm{P}$ concentration $<12$ to $14 \mathrm{mg} \mathrm{kg}^{-1}$. There was no P deficit at other locations, therefore, no fertilizer was applied. Potassium level was sufficient in all locations, and $\mathrm{N}$ fertilizer was not needed.

Nine commercially available smooth pea cultivars were tested at the five locations in 2013 and 2014. The pea cultivars varied in cotyledon color (yellow and green), grain weight, and maturity time. General characteristics of each cultivar and the values measured in the current study are presented in Table 4.

The trials were conducted in a randomized complete block design with three replications at all locations. Commercial rhizobia inoculant (Nodulator, BASF Corporation, Triangle Park NC) was applied to seed at recommended rate from the manufacturer before planting at all locations. Seeds were also pre-treated with Apron MAXX RTA fungicide (Syngenta, Greensboro, NC) to control soil-borne diseases and Cruiser MAXX insecticide (Syngenta, Greensboro, NC) to prevent pea leaf weevil (Sitona lineatus) infestation. Seeds were weighted, treated, and packaged at the coordinator site (Moccasin) then shipped to the other experimental sites. Seeds were planted using a no-till plot drill at a seeding rate of 86 live seeds $\mathrm{m}^{-2}$ in 0.26 to $0.30 \mathrm{~m}$ row spacing at all sites. Plots were $6.0 \mathrm{~m}$ long and $1.5 \mathrm{~m}$ wide.
Plots were harvested with a plot combine and yield was calculated from seed weights and the harvested plot area. A seed sample from each plot was taken for chemical analysis. Seed $\mathrm{N}$ content was determined following Dumas combustion and analysis in an $\mathrm{N}$-analyzer (Series II, PerkinElmer Inc., Wellesley, MA) (Holmes, 1963), then converted to protein content. Resistant and non-resistant starch (NRS) content was measured according to the method explained by McCleary and Monaghan (2002). The TS was the sum of RS and NRS. All values were based on the seed weight at $13 \%(\mathrm{w} / \mathrm{w})$ moisture content.

\section{Data Analysis}

Data were analyzed using the additive main effect and multiplicative interaction (AMMI) methodology following the protocol explained by Gauch (2013). The AMMI analysis was performed using $\mathrm{R}$ statistical software ( $\mathrm{R}$ v. 3.2.2) with Agricolae package (v. 1.2.3), considering the following model:

$$
Y_{i j}=\mu+G_{i}+E_{j}+\sum_{k=1}^{n} \lambda_{k} \xi_{i k} \eta_{j k}+\varepsilon_{i j}
$$

Table 3. Agronomic details of peas growing at each location.

\begin{tabular}{|c|c|c|c|c|c|}
\hline Site conditions and field operations & Conrad & Creston & Havre & Huntley & Moccasin \\
\hline \multicolumn{6}{|c|}{$\underline{2013}$} \\
\hline Site conditions & Dry land & Dry land & Dry land & $\begin{array}{l}\text { Supplementary } \\
\text { irrigated }\end{array}$ & Dry land \\
\hline Previous crop & Barley & Winter wheat & Barley & Barley & Winter wheat \\
\hline Seeding date & 22 May & 17 Apr. & 24 Apr. & 22 Mar. & 19 Apr. \\
\hline Harvesting date & 5 Sept. & I4 Aug. & 6 Aug. & 26 July & 30 July \\
\hline Growing period, day & 106 & 119 & 105 & 126 & 103 \\
\hline Apr.-Aug. rainfall, mm & 204 & 232 & 324 & 273 & 260 \\
\hline Tillage & No-till and rolled & Conventional & Chem Fallow & Disked & No-till and rolled \\
\hline $\mathrm{N}-\mathrm{P}_{2} \mathrm{O}_{5}-\mathrm{K}_{2} \mathrm{O}, \mathrm{kg} \mathrm{ha}^{-1}$ & $6-29-11$ & $0-22-39$ & None & None & None \\
\hline Herbicides and insecticide, $\mathrm{L} \mathrm{ha}{ }^{-1}$ & Roundup Max:1.3† & None & None & RT3:I.6 & RT3: 0.9 Prowl| \\
\hline & $\begin{array}{l}\text { Prowl } \mathrm{H}_{2} \mathrm{O}: 2.1 \ddagger \\
\text { Sevin XLR Plus:2.Iई }\end{array}$ & & & & $\mathrm{H}_{2} \mathrm{O}: 2.4$ Assure II: 0.7\# \\
\hline \multicolumn{6}{|c|}{$\underline{2014}$} \\
\hline Site conditions & Dry land & Dry land & Dry land & Dry land & Dry land \\
\hline Previous crop & Barley & Pea & Winter wheat & Barley & Winter wheat \\
\hline Seeding date & 5 May & 23 Apr. & 20 Apr. & 5 May & 9 Apr. \\
\hline Harvesting date & 6 Aug. & 4 Sept. & 28 July & 4 Aug. & I Aug. \\
\hline Growing period, day & 93 & 133 & 99 & 91 & 114 \\
\hline Apr.-Aug. rainfall, mm & 204 & 265 & 186 & 263 & 323 \\
\hline Tillage & No-till & No-till & No-till & No-till & No-till \\
\hline $\mathrm{N}-\mathrm{P}_{2} \mathrm{O}_{5}-\mathrm{K}_{2} \mathrm{O}, \mathrm{kg} \mathrm{ha}^{-1}$ & $12-24-22$ & $5-23-6$ & None & None & None \\
\hline \multirow[t]{3}{*}{ Herbicides and insecticide, $\mathrm{L} \mathrm{ha}^{-1}$} & Roundup Max:I.3 & Prowl $\mathrm{H}_{2} \mathrm{O}: 4.2$ & RT3:I.75 & RT3: 2.3 & Prowl $\mathrm{H}_{2} \mathrm{O}: 4.2$ \\
\hline & Prowl $\mathrm{H}_{2} \mathrm{O}: 2.1$ & Raptor: $0.2+\dagger$ & & & \\
\hline & Sevin XLR Plus:2.I & Basagran:0.9 $\ddagger \ddagger$ & & & \\
\hline
\end{tabular}

† Roundup Max Glyphosate: N-(phosphonomethyl)glycine.

$\ddagger$ Prowl $\mathrm{H}_{2} \mathrm{O}$ Pendimethalin: $\mathrm{N}$-(I-ethylpropyl)-3,4-dimethyl-2,6-dinitrobenzenamine.

$\S$ Sevin XLR Plus: Carbaryl: I-naphthyl N-methylcarbamate.

II RT3: Glyphosate, $\mathrm{N}$-(phosphonomethyl)glycine, in the form of its potassium salt.

\# Assure II: quizalofop (6)-2-[4-[(6-chloro-2-quinoxalinyl)oxy]phenoxy]propanoic acid.

†† Raptor Imazamox: 2-[4,5-dihydro-4-methyl-4-(I-methylethyl)-5-oxo-IH-imodazol-2-yl]-5-(methoxymethyl)-3-pyridinecarboxylic acid.

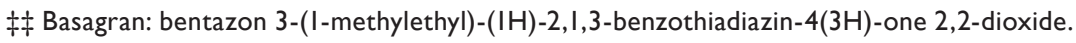



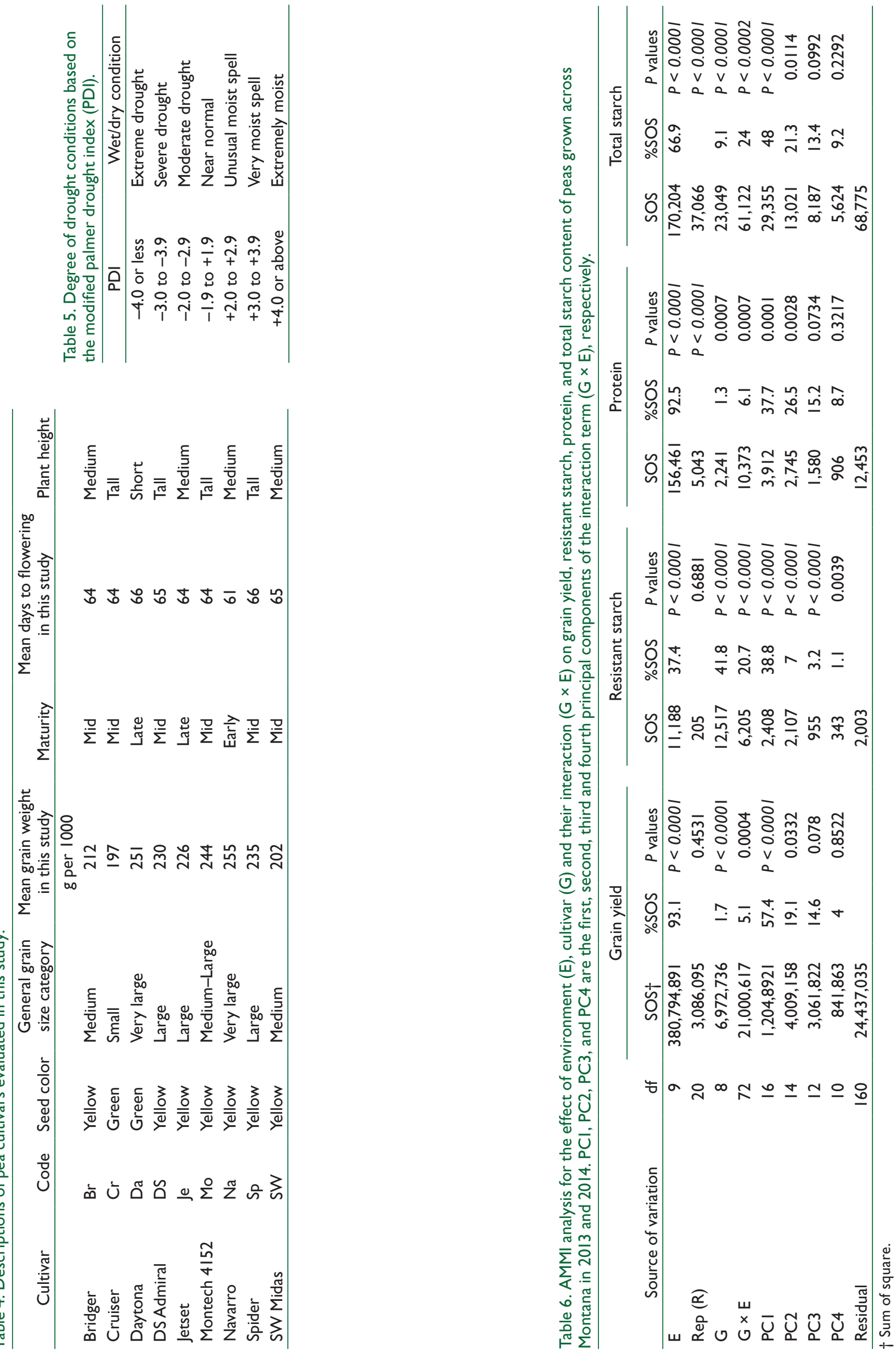
where $Y_{i j}$ is the mean of $i$ th cultivar in environment $j ; \mu$ is the overall mean; $G$ is the effect of cultivar $i$; and $E$ is the effect of environment $j$. The GE interaction is explained by the multiplicative term of the equation where $\lambda$ is the singular value of the principal component (PC) of $k$, $\xi$, and $\eta$ are scores of cultivar $i$ and environment $j$, respectively, for principal component $k . n$ ranges from 0 to the number of $\mathrm{PC}$ required to appropriately describe the model.

To determine if AMMI analysis was valid, the sum of square (SS) of interaction of cultivar $\times$ environment signal (GES), and interaction of cultivar $\times$ environment noise (GEN) were calculated (for details see Gauch, 2013). We found a significant amount of SS for G and GES in the model for yield, protein, and TS but not for RS. Therefore AMMI models were not used for explaining RS variation. In the second step, we ran a model diagnosis to pick the appropriate AMMI biplot to present the results. To do so, we retained as many PCs as needed for the sum of their eigenvalues to approximately equal the SS for GES. Moreover, when two successive members of the model family (AMMI1 and AMMI2 for protein in this study) were nearly tied for maximizing predictive accuracy, the simpler model was presented to simplify interpretation of the results. Therefore, AMMI 1 was selected as the appropriate AMMI model for yield, protein, and TS.

To explain the effect of $E$ on dependent variables we first looked at monthly cumulative rainfall and monthly average air temperature during the growing season at experimental sites. Since raw data of rainfall and temperature were poor in explaining variation in response variables, the modified palmer drought index (PDI) was used. Palmer drought index is an important climatological tool for evaluating the scope, severity, and frequency of prolonged periods of abnormally dry or wet weather (Climate Prediction Center, 2016). From PDI values, seven categories of wet and dry conditions are defined (Table 5).

For each observation, a PDI score was calculated specifically for each cultivar/location/year combination for the phenological stages of establishment (planting to $2 \mathrm{wk}$ after), vegetative ( $2 \mathrm{wk}$ after planting to $1 \mathrm{wk}$ before flowering), flowering $(1 \mathrm{wk}$ before flowering date to $2 \mathrm{wk}$ after), and grain filling (2 wk post flowering to physiological maturity). Weekly values of PDI were
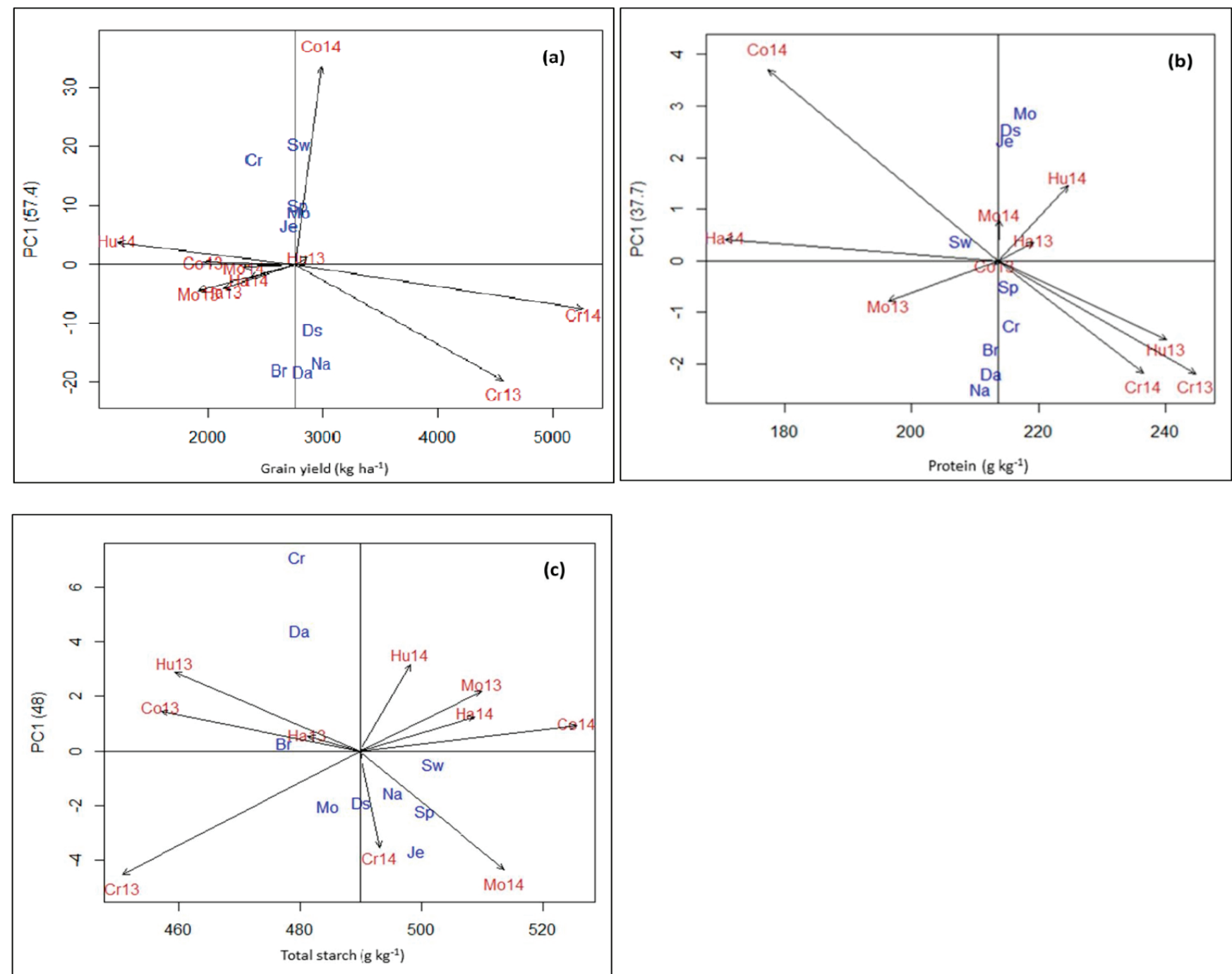

Fig. I. Additive main effect and multiplicative interaction (AMMI); biplot showing (a) yield, (b) protein, and (c) total starch vs. PCI of nine pea cultivars (blue color) and 10 environments (red color). Codes: Bridger (Br), Cruiser (Cr), Daytona (Da), DS Admiral (DS), Jetset (Je), Montech 4I52 (Mo), Navarro (Na), Spider (Sp.), SW Midas (SW). Conrad, 2013 (CO I3), Creston, 2013 (CR I3), Havre, 2013 (HA I3), Huntley, 2013 (HU I3), Moccasin, 2013 (MO I3), Conrad, 2014 (CO I4), Creston, 2014 (CR I4), Havre, 2014 (HA I4), Huntley, 2014 (HU I4), Moccasin, 2014 (MO I4). 
obtained from the Climate Prediction Center and the median value for the period of each phenological stage was taken as the PDI score. Regression analysis was used to assess PDI influence on yield, protein, RS, and TS at different growing stages. Pearson correlation was used to test relationship among yield, protein, RS, and TS. In addition, the relationship between measured characteristics such as grain weight and yield, protein, RS, and TS were also tested using linear regression analysis. Only significant regression models are reported herein.

\section{RESULTS \\ Grain Yield}

Results from ANOVA indicated that $\mathrm{E}$ was the most important source of yield variation explaining $93 \%$ of the total $(G+$ $\mathrm{E}+\mathrm{G} \times \mathrm{E}$ ) sum of squares. The contribution of $\mathrm{G}$ and $\mathrm{G} \times \mathrm{E}$ in total variation was 1.7 and $5.1 \%$ (both significant at $P<0.01$ ), respectively (Table 6).

The AMMI 1 biplot (yield vs. PC1 score) in Fig. 1a shows that pea cultivars represented as a narrow band around $2764 \mathrm{~kg} \mathrm{ha}^{-1}$ (grand mean), while environments covered a larger yield range. Averaged across all environments Navarro was the highest yielding cultivar followed by DS Admiral (Fig. 1a). Navarro was among cultivars with greatest yield, even
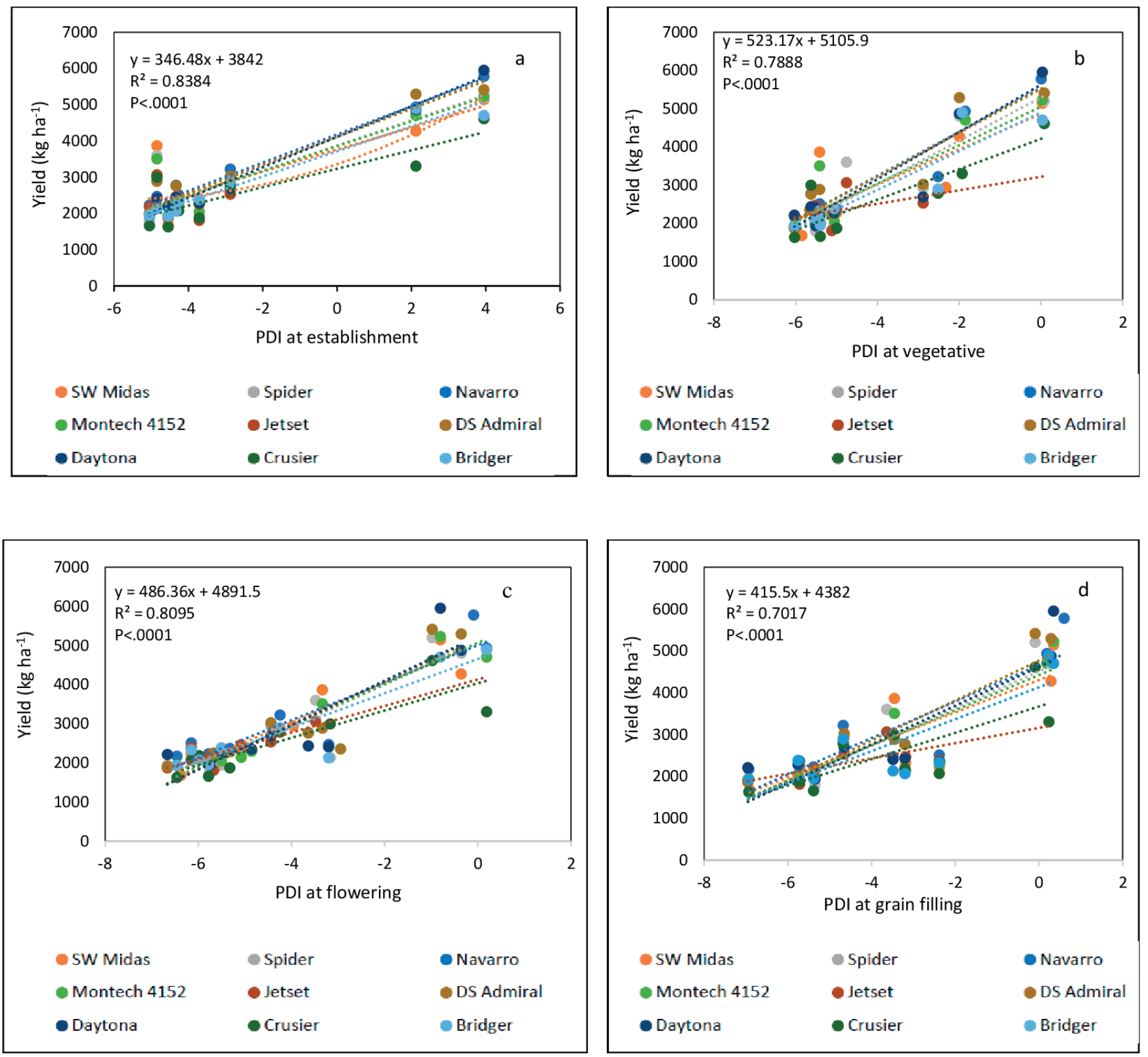

Fig. 2. Relationship between the modified palmer drought index (PDI) and grain yield of pea at various phenological stages ([a] establishment, [b] vegetative growth, [c] flowering, and [d] grain filling). Regression lines are drawn for each cultivar separately but the regressions equation represent the case with all data points being considered.

PDI values and degree of drought: -4.0 or less $=$ extreme drought, -3.0 to $-3.9=$ severe drought, -2.0 to $-2.9=$ moderate drought, -1.9 to $+1.9=$ near normal, +2.0 to $+2.9=$ unusual moist, +3.0 to $+3.9=$ very moist, and +4.0 or above $=$ extremely moist. 
in the environments with low yield potential such as MO 13 and HU 14 (data not shown). In contrast, Cruiser and Bridger were the lowest yielding cultivars. Creston notably out-yielded other sites in both years of the experiment. In this biplot, the cultivars and environments appearing closer to the horizontal reference line at $\mathrm{PC1}=0$ indicate a greater relative stability or general adaptation (Gauch, 2013). Accordingly, yields of Jetset, Montech 4152, and Spider were more stable than the others, whereas other cultivars strongly interacted with the environments showing their specific adaptation to the environments with PC1 scores of the same sign (Fig. 1a). Therefore, Jetset, Montech 4152, and Spider showed relatively general adaptation.

A linear and significant regression was found between yield and PDI at all four growth stages (Fig. 2). It should be noted that, except at establishment, the highest PDI values never exceeded one during the other three growth stages of pea (vegetative growth, flowering, and grain filling) in this study. In the range of -7 to 1 of PDI values, we found that yield response to PDI values was a linear and positive, showing that yields were limited under drought. Comparing the regression lines (slopes), cultivars responded differently to PDI showing different susceptibility to drought among the cultivars, especially at later phenological stages. Moreover, moisture availability at vegetative growth stage seemed to have a greater impact on final yield compared to that at other growth stages (based on the slopes of the regression lines).

A positive relationship $\left(R^{2}=0.57, P=0.0115\right)$ was found between grain weight and grain yield of cultivars when averaged across all environments (Fig. 3a).

\section{Resistant Starch}

As shown in Table 6, RS was significantly influenced by $G$ $(P<0.01), \mathrm{E}(P<0.01)$, and $\mathrm{G} \times \mathrm{E}(P<0.01)$. In contrast to yield, RS content was greatly influenced by cultivar ( $42 \%$ of the total variation). Cruiser and Jetset tightly compete with each other in RS ranking and both contained $31.1 \mathrm{~g} \mathrm{~kg}^{-1}$ of $\mathrm{RS}$ averaged across all environments which was significantly higher than any other tested cultivar. Navarro $\left(12.3 \mathrm{~g} \mathrm{~kg}^{-1}\right)$ and Montech $4152\left(14.6 \mathrm{~g} \mathrm{~kg}^{-1}\right)$ had the lowest content of RS, considerably lower than the grand mean of $21.1 \mathrm{~g} \mathrm{~kg}^{-1}$ (Table 7). It is worth noting that Navarro, the cultivar that ranked top in grain yield, contained very low levels of RS whereas Cruiser, a cultivar with below-average yield, contained high levels of RS.

There was no significant correlation between RS and PDI at any phenological growth stages of pea. The RS content was negatively correlated with grain weight (Fig. 3b).
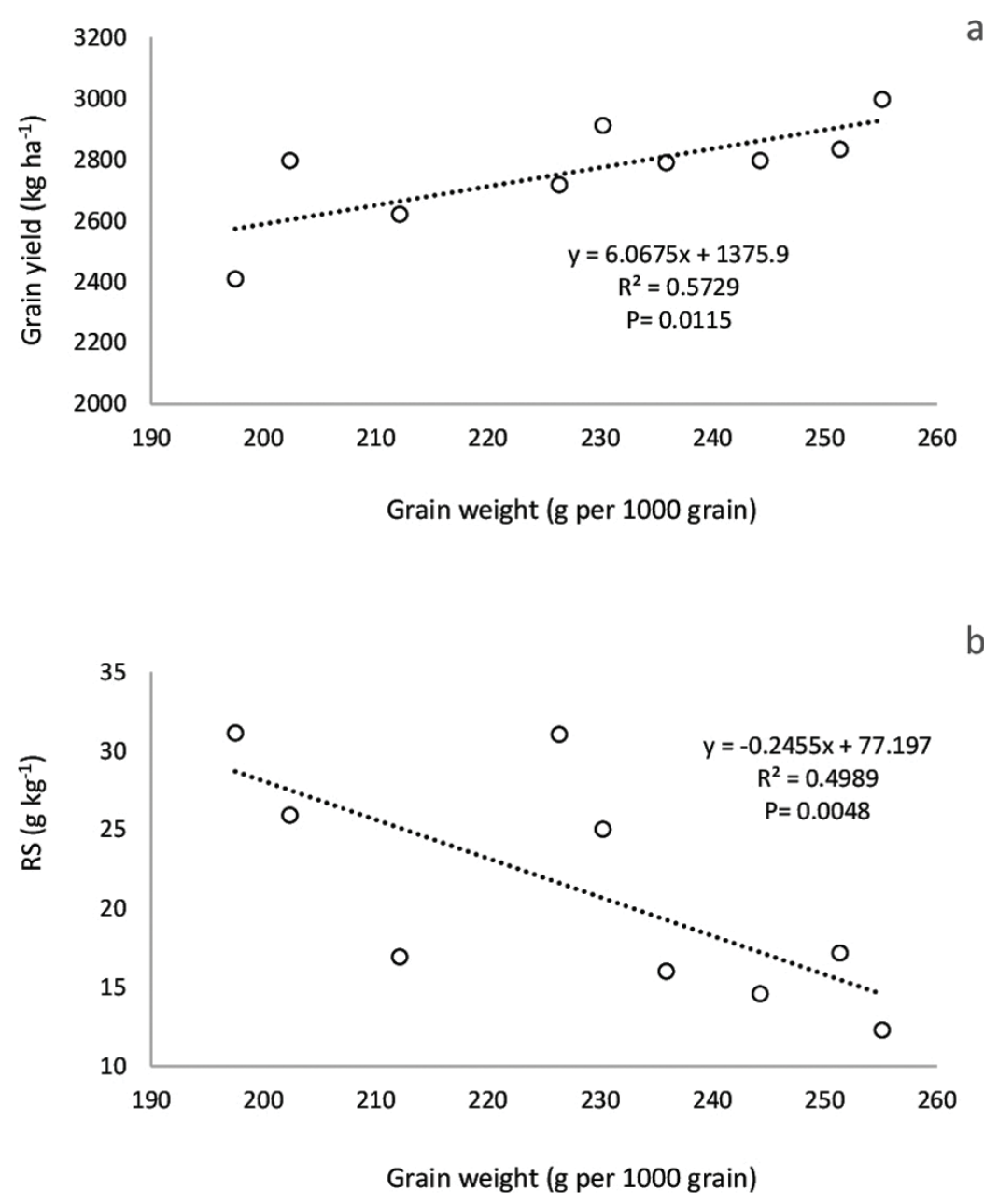

Fig. 3. Relationship (a) between yield and grain weight and (b) between resistant starch (RS) and grain weight of pea. The values are average number for each cultivar across locations and years. 
Table 7. Mean resistant starch content $\left(\mathrm{g} \mathrm{kg}^{-1}\right)$ in dry pea cultivars grown at five locations during 2013 and 2014 across Montana. The highest value within each column is bolded.

\begin{tabular}{|c|c|c|c|c|c|c|c|c|c|c|c|}
\hline \multirow[b]{2}{*}{ Cultivar } & \multicolumn{5}{|c|}{2013} & \multicolumn{5}{|c|}{2014} & \multirow[b]{2}{*}{ Mean } \\
\hline & Conrad & Creston & Havre & Huntley & Moccasin & Conrad & Creston & Havre & Huntley & Moccasin & \\
\hline & & & & & & $\mathrm{kg}^{-1}$ & & & & & \\
\hline Bridger & 5.5 & 13.4 & 16.0 & 12.3 & 25.0 & 19.8 & 18.4 & 20.0 & 21.6 & 17.5 & 16.9 \\
\hline Cruiser & 12.3 & 18.7 & 27.6 & 26.2 & 45.4 & 29.0 & 53.2 & 31.2 & 34.7 & 33.1 & 31.1 \\
\hline Daytona & 5.5 & 12.7 & 17.1 & 10.8 & 23.2 & 19.9 & 28.6 & 20.2 & 16.5 & 17.3 & 17.2 \\
\hline DS Admiral & 8.8 & 18.2 & 26.4 & 13.7 & 28.6 & 24.9 & 39.4 & 29.8 & 35.7 & 24.8 & 25.0 \\
\hline Jetset & 12.4 & 34.6 & 23.3 & 17.1 & 32.5 & 36.3 & 48.4 & 29.3 & 45.6 & 31.2 & 31.1 \\
\hline Montech 4I52 & 5.3 & 12.0 & 13.5 & 10.1 & 26.0 & 20.6 & 16.6 & 14.8 & 13.9 & 13.3 & 14.6 \\
\hline Navarro & 6.6 & 10.8 & 9.6 & 9.0 & 16.0 & 14.9 & 12.5 & 14.0 & 12.2 & 17.1 & 12.3 \\
\hline Spider & 5.2 & 17.6 & 17.2 & 8.4 & 16.8 & 22.2 & 23.0 & 20.2 & 15.1 & 14.6 & 16.0 \\
\hline SW Midas & 8.5 & 17.3 & 22.6 & 16.3 & 33.9 & 32.5 & 37.8 & 26.6 & 16.8 & 47.0 & 25.9 \\
\hline $\operatorname{LSD}(P<0.05)$ & 2.4 & 4.6 & 6.3 & 7.6 & 8.0 & 6.1 & 6.8 & 5.8 & 6.8 & 5.0 & 1.8 \\
\hline
\end{tabular}

\section{Protein Content}

The AMMI analysis revealed that $92 \%$ of the total variation in protein content was related to $\mathrm{E}$, whereas $\mathrm{G}$ and $\mathrm{G} \times \mathrm{E}$ explained 1 and $6 \%$ of the total variation $(P=0.0007$ for both), respectively (Table 6).

Protein content in Creston (CR13 and CR14) followed by Huntley (HU13 and HU14) were higher than those in other sites (Fig. 1b). Montech 4152 had the greatest content of protein while SW Midas showed the lowest protein. Spider had greater than average protein content and showed great stability for this trait across the environments.

There was a significant quadratic relationship between PDI and protein at the establishment (Fig. 4a) and at the vegetative growth stages (Fig. 4b). Pearson correlation analysis showed that yield and protein were positively correlated (Table 8).

\section{Total Starch}

Pea TS was mainly affected by E (67\% of the total variation), nevertheless, the effects of $\mathrm{G}$ and $\mathrm{G} \times \mathrm{E}$ were also significant at $P<0.01$ (Table 6).

In contrast to RS, range of variation for TS among pea cultivars was relatively small (Fig. 1c). The highest mean TS content was observed at Conrad 2014 (CO14), whereas pea grown in Creston 2013 (CR13) and Conrad 2013 (CO13) contained the lowest TS. Several cultivars, such as Cruiser and Jetset, had large (positive or negative) PC1 values, indicating specific adaptations (higher TS at certain locations). Averaged over all environments, SW Midas had the greatest contents of total starch. Pearson correlation analysis (Table 8) showed a negative

Table 8. Pearson correlation $(n=270)$ coefficients (and $P$ values in italics) between grain yield, protein, resistant starch (RS), and total starch (TS) in dry pea grown across Montana (nine cultivars, 2 yr, five experimental sites, and three replications at each site).

\begin{tabular}{lcccc}
\hline Variables & Grain yield & Protein & RS & TS \\
\hline Grain yield & I & & & \\
\multirow{2}{*}{ Protein } & 0.39 & 1 & & \\
\multirow{2}{*}{ RS } & $<0.0001$ & & & \\
& 0.10 & -0.11 & 1 & \\
TS & 0.0885 & 0.0776 & & \\
& -0.15 & -0.51 & 0.36 & 1 \\
& 0.0153 & $<0.0001$ & $<0.0001$ & \\
\hline
\end{tabular}

relationship between TS and protein $(r=-0.51, P<0.001)$ and between TS and yield $(r=-0.15, P=0.0153)$.

\section{DISCUSSION}

Environment was the most important driving factor in pea grain yield determination, with a large gap between the average yield at the high yield potential site and other locations. Hence, the genetic and physiological potential of the cultivars are high, but actual yields were extremely limited by the environmental conditions at locations other than Creston. In both years and during all four distinct phenological stages, Creston had the highest PDI values compared to other sites. Relatively moist condition resulted in a considerably higher yield of all cultivars at this site compared to other locations. It should be noted that, except during the establishment, PDI values did not exceed 1 (even at Creston) in this study, which means that too-wet conditions did not occur in this study. Therefore, drought was likely the major cause of huge yield gap between Creston and the other locations across Montana. Other environmental variables not evaluated in this study, such as soil conditions, especially soil depth (which affects water holding capacity in rain-fed systems) may also play important roles in pea yield determination. Cultivars responded differently to dry conditions, suggesting opportunities to select better-adapted cultivars and/or avoid planting sensitive cultivars in drier areas.

The effect of cultivar on pea grain yield was relatively small, much smaller than that of environment. On the other hand, the rank of cultivar performance varied greatly by environment, reflecting site-specific adaptability of cultivars. This suggests that breeding efforts could be more successful if attention is given to the regional interests rather than to make a superior cultivar with general adaptability. For example, in the condition of this study, Navarro outperformed other cultivars in low yield potential sites (Moccasin, Huntley, and Havre), whereas in the highest yield potential environment (Creston), Daytona was the best yielding cultivar. Navarro is among the earliest flowering pea cultivars in the U.S. NGP with an extended flowering period and early maturity (Kandel and Endres, 2010), which likely makes it more resilient to environmental constraints. Daytona, on the other hand, has shown excellent lodging resistance, which seems to be a crucial prerequisite in high-yielding environments, like Creston. The importance of lodging resistance to achieve a higher yield in pea has been 
previously pointed out by others (Annicchiarico and Iannucci, 2008; Podgórska-Lesiak and Sobkowicz, 2013).

Our results showed that cultivars with larger seed tended to produce a higher yield. This could be due to better seedling survival, thus better crop stands of larger-seeded cultivars (Singh et al., 2009), which ultimately could produce higher yields compared to the small-seeded cultivars. Larger seed is also an important yield component contributing to a higher yield if large- and small-seeded plants produce same amount of pods and seed numbers. Further studies are needed to evaluate large seed trait.

Unlike grain yield, the RS content in pea was controlled by cultivar to a greater extent. The range of variation in $\mathrm{RS}$ contents among pea cultivars in this study was significant. Variation among pea cultivars with respect to RS could contribute to their gel structural properties, granule size, amylose/ amylopectin ratio, swelling index, etc., which are not well studied yet (Rahman et al., 2007). More research is required to determine the genetic influences on starch biosynthesis in dry
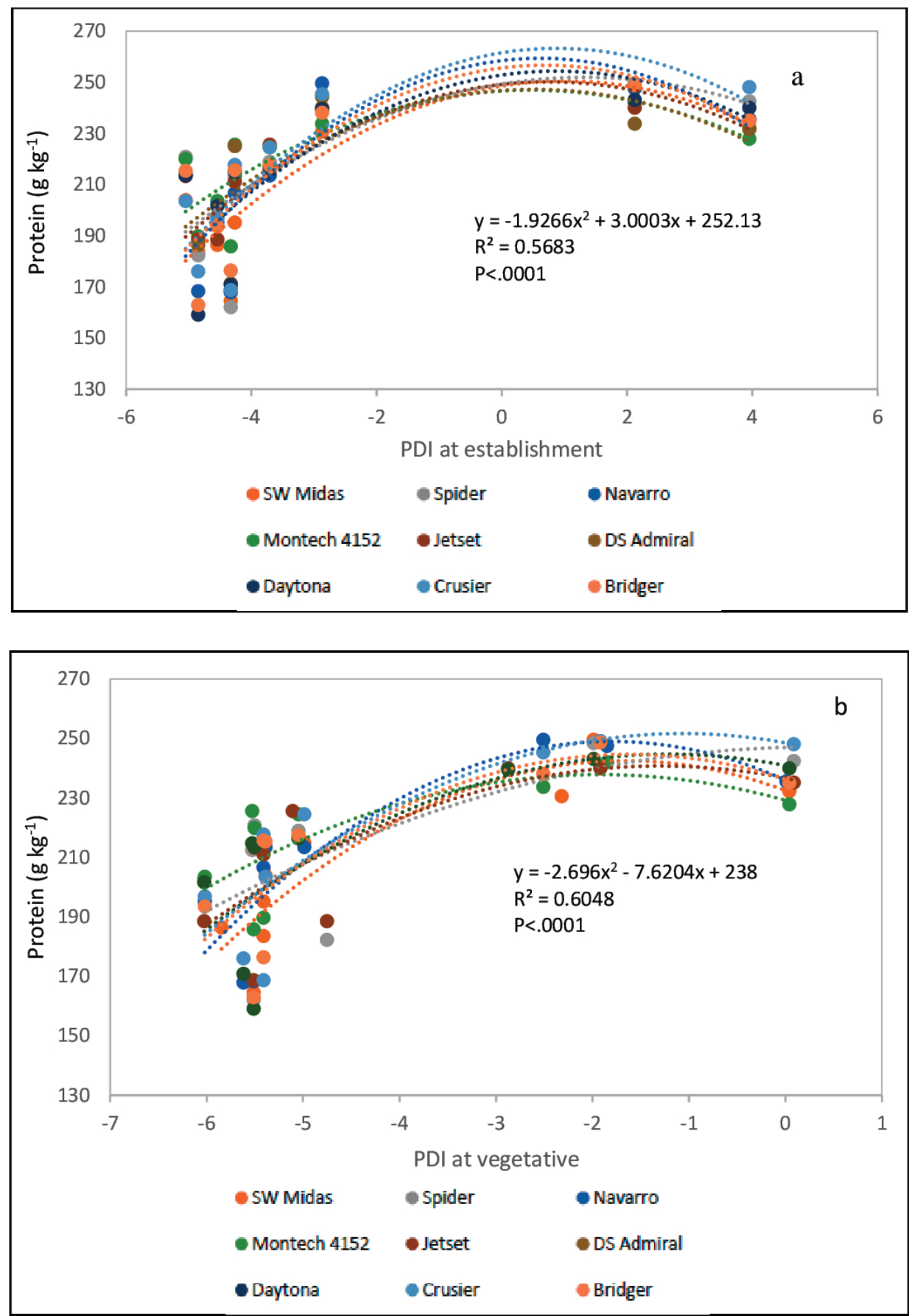

Fig. 4. Relationship between the modified palmer drought index (PDI) and protein content of pea at the (a) establishment and (b) vegetative growth stage. Regression lines are drawn for each cultivar separately but the regressions equation represents the case with all data points being considered. Data of Huntley 2014 were not included. PDI values and degree of drought: -4.0 or less $=$ extreme drought, -3.0 to $-3.9=$ severe drought, -2.0 to $-2.9=$ moderate drought, -1.9 to $+1.9=$ near normal, +2.0 to $+2.9=$ unusual moist, +3.0 to $+3.9=$ very moist, and +4.0 or above $=$ extremely moist. 
pea. In this study, we also found a significant negative correlation between grain weight and RS. Small-seeded cultivars are likely to contain higher levels of RS which makes them better options for specific users such as diabetics.

Protein in pea was mainly determined by E. A significant quadratic relationship between protein content and PDI during the establishment as well as during vegetative growth stage indicates that too dry and/or too wet condition at early growth stages can limit protein accumulation in pea. Some researchers have pointed out that less precipitation is favorable for protein accumulation in peas (Al-Karaki and Ereifej, 1999; Nikolopoulou et al., 2007), however, there is a lack of information in the literature regarding the effect of rainfall distribution throughout the growing season (or phenological stages) on pea protein. Our results suggest that wetter condition during establishment and vegetative growth stages (April-June) has a positive effect on pea protein content. This could be attributed to a better overall growth and development, thus a higher potential for biological $\mathrm{N}$ fixation under a wetter condition at this period.

Protein content also significantly varied among the cultivars. It has been shown that the potential of biological $\mathrm{N}$ fixation varies greatly among pea cultivars (Abi-Ghanem et al., 2013). This reveals a unique opportunity for improving $\mathrm{N}$ fixation, protein content, and yield in pea breeding programs through the genetic crossing and selection. Further studies are needed to evaluate $\mathrm{N}$-fixation ability among pea cultivars.

As mentioned previously, the content of RS is nutritionally important with higher content of RS is desirable (Rahman et al., 2007). From the farmer's point of view, however, a cultivar containing high levels of RS is considered valuable only if it has the potential to produce acceptable grain yield, otherwise, will not be selected. Although growers are currently paid based on yield only and no premium is paid for starch or protein, processing facilities value the quality of the product (based on their interest). For example, based on the corresponding author's personal communication with processors, the market value of dry pea protein is considerably higher than starch in China (US\$500 vs. \$66 per metric tonnes). Therefore, requirements of the target market should play an important role in breeding efforts and cultivar recommendations. For example, Navarro showed a high yield at all tested environments with a good yield stability accompanied by high total starch. However, its protein was below average and its $\mathrm{RS}$ was also very low. DS Admiral should be better options for yield and protein. Also, DS Admiral showed a high yield accompanied with high RS content. Overall, DS Admiral could be judged as a promising cultivar with above average yield, RS, and protein for the condition of this study.

The results of this study can provide useful information to breeders and agronomists toward enhancing yield and quality of dry pea production in dryland environments in general and in the U.S. NGP specifically. Hopefully, this information can also guide farmers in different regions to select and grow high yielding and good quality pea.

\section{CONCLUSION}

This study revealed that environment is the most important driving factor in pea grain yield, protein, and TS determination, whereas RS content is under the control of genetic to a great extent. Drought at all stages limited pea yield, but different cultivars tended to respond to drought differently. The yield was positively correlated with protein, implying a potential to select/breed a cultivar with higher yield and protein based on target markets need and desirability. Protein was negatively correlated with TS, thus protein- or starch-type cultivars may be bred for different end-users.

\section{ACKNOWLEDGMENT}

The authors want to acknowledge Peggy Lamb, Kent McVay, Qasim Khan, Brooke Bohannon, and John Miller for providing the pea samples from the field variety trials conducted at the five agricultural research centers. The field studies were supported by the USA Dry Pea and Lentil Council and Montana Agricultural Experiment Station, and the laboratory studies on protein and starch were supported by the Montana Specialty Crop Block Grant Project (Grant no. 12-25-B-1079).

\section{REFERENCES}

Abi-Ghanem, R., E.T. Bodah, M. Wood, and K. Braunwart. 2013. Potential breeding for high nitrogen fixation in Pisum sativum L.: Germplasm phenotypic characterization and genetic investigation. Am. J. Plant Sci. 4:1597-1600. doi:10.4236/ ajps.2013.48193

Al-Karaki, G.N., and K.I. Ereifej. 1999. Relationships between seed yield and chemical composition of field peas grown under semiarid Mediterranean conditions. J. Agron. Crop Sci. 182:279284. doi:10.1046/j.1439-037x.1999.00298.x

Annicchiarico, P., and A. Iannucci. 2008. Adaptation strategy, germplasm type and adaptive traits for field pea improvement in Italy based on variety responses across climatically contrasting environments. Field Crops Res. 108:133-142. doi:10.1016/j. fcr.2008.04.004

Birt, D.F., T. Boylston, S. Hendrich, J.L. Jane, J. Hollis, L. Li et al. 2013. Resistant starch: Promise for improving human health. Adv. Nutr. 4:587-601. doi:10.3945/an.113.004325

Chen, C., G. Jackson, K. Neill, and J. Miller. 2006. Spring pea, lentil, and chickpea response to phosphorus fertilizer. Fertilizer Facts 38. Montana State Univ., Agric. Exp. Stn. and Ext. Serv., Bozeman.

Chen, C., K. Neill, M. Burgess, and A. Bekkerman. 2012. Agronomic benefit and economic potential of introducing fall-seeded pea and lentil into conventional wheat-based crop rotations. Agron. J. 104:215-224.

Chiu, Y.T., and M.L. Stewart. 2012. Effect of cultivar and cooking method on resistant starch content of white rice and subsequent postprandial glucose response and appetite in humans. Asia Pac. J. Clin. Nutr. 22:372-379.

Climate Prediction Center. 2016. Climate Prediction Center. http:// www.cpc.ncep.noaa.gov/ (accessed 10 Dec. 2015).

Gauch, H.G. 2013. A simple protocol for AMMI analysis of yield trials. Crop Sci. 53:1860-1869. doi:10.2135/cropsci2013.04.0241

Haenen, D., J. Zhang, C.S.D. Silva, G. Bosch, I.M.V. Meer, J.V. Arkel, and G.J. Hooiveld. 2013. A diet high in resistant starch modulates microbiota composition, SCFA concentrations, and gene expression in pig intestine. J. Nutr. 143:274-283. doi:10.3945/ jn.112.169672

Hazard, B., X. Zhang, P. Colasuonno, C. Uauy, D.M. Beckles, and J. Dubcovsky. 2012. Induced mutations in the genes increase amylose and resistant starch content in durum wheat. Crop Sci. 52:1754-1766.

Holmes, F.L. 1963. Elementary analysis and the origins of physiological chemistry. Isis 54:50-81. doi:10.1086/349664 
Hood-Niefer, S.D., T.D. Warkentin, R.N. Chibbar, A. Vandenberg, and R.T. Tyler. 2012. Effect of genotype and environment on the concentrations of starch and protein in, and the physicochemical properties of starch from, field pea and fababean. J. Sci. Food Agric. 92(1):141-150. doi:10.1002/jsfa.4552

Ito, D., R. Keshavarz Afshar, C. Chen, P. Miller, K. Kephart, K. McVay et al. 2016. Multi-environmental evaluation of dry pea and lentil cultivars in Montana using AMMI model. Crop Sci. 56:520-529. doi:10.2135/cropsci2015.01.0032

Kandel, H., and G. Endres. 2010. North Dakota dry pea performance testing. North Dakota State Univ. http://www.ag.ndsu.edu/ pubs/plantsci/rowcrops/a1469.pdf (accessed 10 Oct. 2015).

Long, J.A., R.L. Lawrence, P.R. Miller, L.A. Marshall, and M.C. Greenwood. 2014. Adoption of cropping sequences in northeast Montana: A spatio-temporal analysis. Agric. Ecosyst. Environ. 197:77-87. doi:10.1016/j.agee.2014.07.022

McCleary, B.V., and D.A. Monaghan. 2002. Measurement of resistant starch. J. AOAC Int. 85:665-675.

Nikolopoulou, D., K. Grigorakis, M. Stasini, M.N. Alexis, and K. Iliadis. 2007. Differences in chemical composition of field pea (Pisum sativum) cultivars: Effects of cultivation area and year. Food Chem. 103:847-852. doi:10.1016/j. foodchem.2006.09.035

Podgórska-Lesiak, M., and P. Sobkowicz. 2013. Prevention of pea lodging by intercropping barley with peas at different nitrogen fertilization levels. Field Crops Res. 149:95-104. doi:10.1016/j. fcr.2013.04.023

Rahman, S., A. Bird, A. Regina, Z. Li, J.P. Ral, S. McMaugh, D. Topping, and M. Morell. 2007. Resistant starch in cereals: Exploiting genetic engineering and genetic variation. J. Cereal Sci. 46:251-260. doi:10.1016/j.jcs.2007.05.001
Ratnayake, W.S., R. Hoover, and T. Warkentin. 2002. Pea starch: Composition, structure and properties - A review. Starke 54:217-234. doi:10.1002/1521-379X(200206)54:6<217::AID STAR217>3.0.CO;2-R

Sajilata, M.G., R.S. Singhal, and P.R. Kulkarni. 2006. Resistant starch-a review. Comprehensive Review Food Sci. Food Safety 5:1-17. doi:10.1111/j.1541-4337.2006.tb00076.x

Singh, N.I., S. Ali, and J.S. Chauhan. 2009. Effect of seed size on quality within seed lot of pea and correlation of standard germination, vigour with field emergence test. Nature Sci. 7:72-78.

Strydhorst, S., M. Olson, T. Vasanthan, K.E. McPhee, R.H. McKenzie, B. Henriquez et al. 2015. Adpatability and quality of winter pea and lentil in Alberta. Agron. J. 107:2431-2448. doi:10.2134/agronj15-0092

Sun, J., D. Wu, J. Xu, S.K. Rasmussen, and X. Shu. 2015. Characterisation of starch during germination and seedling development of a rice mutant with a high content of resistant starch. J. Cereal Sci. 62:94-101. doi:10.1016/j.jcs.2015.01.002

Tan, H.Z., Z.G. Li, and B. Tan. 2009. Starch noodles: History, classification, materials, processing, structure, nutrition, quality evaluating and improving. Food Res. Int. 42:551-576. doi:10.1016/j.foodres.2009.02.015

Tzitzikas, E.N., J.P. Vincken, and J. DeGroot. 2006. Genetic variation in pea seed globulin composition. J. Agric. Food Chem. 54:425-433. doi:10.1021/jf0519008

USDA-NASS. 2014. Data and statistics/quick stats. USDA-NASS, Washington, DC. http://www.nass.usda.gov/Data_and_Statistics/Quick_Stats_1.0/index.asp (accessed 24 Nov. 2016).

Wen, G., C. Chen, K. Neill, D. Wichman, and G. Jackson. 2008. Yield response of pea, lentil and chickpea to phosphorus addition in a clay loam soil of central Montana. Arch. Agron. Soil Sci. 54(1):69-82. doi:10.1080/03650340701614239 